\title{
HIGHLIGHTING AMBIGUITIES: THE FICTIONALIZATION OF A WOMAN'S LIFE IN LORENZA REYNAFÉ O QUIROGA, LA BARRANCA DE LA TRAGEDIA
}

Sally Webb Thornton Indiana University of Pennsylvania

The role of fabrication in historical accounts and of veracity in fictional tales continues to intrigue and frustrate, for however strict a dichotomy is proclaimed between truth and invention, there is no indisputable line to be drawn; ultimately all narration is story filtered through a personal perception. Those who have limited the telling and retelling of stories of nation building in the New World to ideological accounts of the acts and lives of great figures, overwhelmingly male, have been challenged in recent decades by versions by and about women. The historian Carolyn Steelman writes about the desire of women for "narratives that will explain and give meaning to so many lost lives, to what we understand to have been so much silence and repression,"1 while the literary critic Carmen Pirelli declares that these feminine narratives serve a double purpose: first, a historical revision of woman's place within a historical framework, and second, an attack on the of ficial versions of history whether they be from the political right or left. ${ }^{2}$

1. Carolyn Steelman, “La Théorie Qui N'Est Pas Une, or Why Clio Doesn't Care,” History and Feminist Theory. Ed. Ann-Louise Shapiro (Middleton, CT: Wesleyan University Press, 1992) 42.

2. Carmen Pirelli, Ed. "Relatos de caudillos y señoritas. Historiografía, ficción, y género en la narrativa latinoamericana," Estructuras alternativas en Latinoamérica (Tucumán: Instituto Interdisciplinario de Estudios Latinoamericanos, 1995) 16. 
In her novel Lorenza Reynafé o Quiroga la barranca de la tragedia Mabel Pagano not only recovers fictionally the historical figure of Lorenza Reynafé, but also breaks the silence surrounding the women who participated in the creation of Argentina in the nineteenth century. In so doing, her redemption of the female protagonist's story highlights the ambiguity of the various standard historical accounts of one particular event, the assassination of Facundo Quiroga in 1835, which in turn points to a pluralization of possibilities for the interpretation of all official history. According to Perilli, this type of fiction causes an unforeseen effect:

la ruptura con la naturalización de la palabra histórica presentada como res gestae [n]os convoca a asistir al reconocimiento de que, si bien el evento existe, sólo podemos conocerlo bajo la forma de una trama en la que intervienen la imaginación y el lenguaje. $^{3}$

The historical Lorenza Reynafé, the third of nine siblings, was the sister of the four men accused of planning the murder of the caudillo Facundo Quiroga and eight other members of his party, a stroke executed by the gaucho Captain Santos Pérez and his men on February 16, 1835 about 50 miles outside of Córdoba at Barranca Yaco. This place name gives a double meaning to the word "barranca" in the title of Pagano's novel based on the event: "Barranca Yaco," the place where the assassination occurs, and "barranca de la tragedia," or the Reynafé family's descent into tragedy. The murder of Quiroga has excited the popular and inscribed imagination ever since it occurred, especially because of the strong suspicions that president Rosas may have set up the murder in order to eliminate a political rival; but also because there was contradictory testimony in regard to the strength of

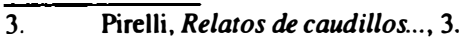


the evidence which convicted the four Reynafé brothers. All were found guilty and condemned to death by the Rosas government.

Historical versions of this event range from exonerating to condemning the Reynafé brothers. In his study Facundo Quiroga, Barranca Yaco: Juicios y Testimonios Armando Zárate provides examples from the various accounts and historical interpretations as well as from popular cancionero and fictional versions. Eduardo Gutiérrez' fictional work Juan Manuel de Rosas ${ }^{4}$ supports the brothers, andBorges poem "El General Quiroga va en coche al muere" implicates Rosas ("muerte de mala muerte se lo llevó al riojano, y una de puñaladas lo mentó a Juan Manuel"). ${ }^{5}$ Zárate highlights the way that the assassination has affected the imagination of writers of history and fiction:

Barranca Yaco ha sido - y puede seguir siéndolo - una encrucijada de caminos para el análisis y la crítica histórica. Intensa, como igualmente persistente, ha sido la obra de los publicistas que no han pasado por alto el problema sin infundirle todas las formas de inculpación, pasiones y criterios... La mayoría de las memorias no son un género imparcial... 6

...muchos años más tarde, entre poetas cultos y bien cotizados, la emboscada de Barranca Yaco anima todavía con misterio inusitado o arquetípico, la ficción, el poema, y el drama. ${ }^{7}$

Sobre Barranca Yaco se escribe, y se seguirá escribiendo. ${ }^{8}$

4. $\quad$ Eduardo Gutiérrez, Juan Manuel de Rosas (Buenos Aires: Harpón, 1944).

5. Jorge Luis Borges, "El General Quiroga va en coche al muere," In Armando Zárate, Facundo Quiroga, Barranca Yaco: juicios y testimonios (Buenos Aires: Plus Ultra, 1985).

6. Armando Zárate, Facundo Quiroga, Barranca Yaco: juicios y testimonios (Buenos Aires: Plus Ultra, 1985) 45.

7. Zárate, 139.

8. Zárate, 141. 
Pagano's imagination has also been stirred by this event. However, she chooses to narrate a version by and about another member of the family, a representative of the silent half of history, womankind. As Jean Franco has emphasized, most of our versions of history are the stories of nations by and about men:

In national allegories, women became the territory over which the quest for (male) national identity passed...

Under these circumstances, national identity could not but be a problematic terrain for women novelists. How could they plot themselves into a narrative without becoming masculine or attempting to speak from a devalued position? ${ }^{9}$

This is Pagano's dilemma, and she proceeds by giving voice in the novel ${ }^{10}$ to Lorenza and presenting her as a strong, intelligent, independent, and dynamic protagonist who is trusted advisor to her politically and militarily active brothers. Because she is a woman, Lorenza's involvement would not be visible to those recording the nation's early history. Thus, Pagano must give her, and by extension other women, both a voice and a presence in the process of nation building. At first, Lorenza's story resembles a fairy tale. She is born in 1786, the attractive, well-loved daughter of wealthy, land-owning parents in Los Manantiales in the province of Córdoba where some thirty prominent families live. In the novel, Lorenza's father describes her as a person who loves to read and learn from others. She and two of her sisters receive schooling in Tulumba. However, at the age of twenty-one, Lorenza's mother as well as an older and a younger sister die, leaving her as the oldest female in a household consisting of a father who is increasingly unable to tend to the family affairs and seven surviving siblings. She decides to remain at Los Manantiales instead

9. Jean Franco, Plorting Women: Gender and Representation (New York: Columbia University Press, 1989) 132-133. 
of retuming to school in Tulumba, because in the novel, in addition to her family responsibilities is the fact that she is in love with her neighbor, Pedro Caminos, a widowed soldier with a young daughter. Although Pedro wants to marry Lorenza, she postpones her decision because of a strong sense of duty to her family. The delay caused by Lorenza's increasing administration of the familial properties and involvement in family affairs coupled with miscommunications and the complications of Pedro's soldiering in this difficult time in Argentina's history are all reasons why Lorenza and Pedro never marry, though he marries two more times. Lorenza is thus fictionally portrayed as capable and very involved in the administration of family properties and affairs, though traditional in the sense that she seems always to be sacrificing her own personal happiness for the welfare of others. But through this fictional Lorenza, Pagano proposes an alternate view of traditional nineteenth-century woman: a woman sometimes very involved in and important to the nation-building process. Pagano proposes that her life is not the "historical blank page" that history books would have us infer. The novelized Lorenza does not shrink from expressing her opinions or from involvement in political life. Her decision not only to nurture, but to know her brothers and their activities leads to her active mentoring of them even after they become soldiers or marry and leave the family home. She remains there as the center of life in Los Manantiales and continues capably administering and protecting the family interests after the death of her father:

...desde la cocina al escritorio, ... revisaba hasta el último de los papeles de la estancia familiar y también los de las propiedades de sus hermanos, que vivían más tranquilos sintiendo que los ojos de Lorenza estaban atentos sobre sus intereses y todo su temple les cuidaba las espaldas. ${ }^{11}$

$\overline{10 . \quad A l l ~ q u o t e s}$ from the novel will be from the following edition: Mabel Pagano, Lorenza Reynafe o Quiroga, la barranca de la tragedia (Buenos Aires: Ada Kom, 1991). 
At the same time she is increasingly aware of the encroaching political turmoil: "me doy cuenta de que alrededor las cosas van cambiando y que no es posible dejar afuera de nuestras puertas las inquietudes que dominan a la gente". ${ }^{12}$ To complicate matters, Lorenza becomes involved in a lawsuit and instead of backing down, defends her honor vigorously even though the whole family blames her for having involved them in a scandal. She ponders whether or not it would have been preferable: "callarme como cualquier otra mujer hubiera hecho en mi lugar; no responder a la injuria, esperar que pasara la tormenta". ${ }^{13}$ But her style is one of active involvement in all areas, and instead of wasting away because her one true love is never fulfilled, she accepts two offers of employment, first for a doctor, organizing his papers, and later for the Vicar General of Córdoba, managing his affairs.

Her brothers are now fully committed politically, and her comment that: "[e]se federalismo de que tanto hablan, quizás cueste mucho más de lo que todos esperan"14 is prescient. The struggle is as much between the Federalists Facundo Quiroga and Estanislao López as it is against the Unitarian partisans, and Lorenza understands both the inevitability and the necessity of the conflict: "todo el país se verá envuelto en las luchas. Y no podremos evitarlas, porque es la continuidad de la República o su desaparición lo que se pondrá en juego." ${ }^{15}$ Following the deaths of her employers, and upset by rumors that two of her brothers have been exiled to Salta for their political activities, Lorenza returns to Los Manantiales. However, in the novel she spends much time traveling around in order to talk with her brothers and stay involved, because, she laments: "a mí no era posible encerrarme como mis cuñadas; no hubiera podido soportar el no saber qué estaba

$\begin{array}{ll}\text { 11. } & \text { Pagano, } 85 . \\ \text { 12. } & \text { Pagano, } 89 . \\ \text { 13. } & \text { Pagano, 110. } \\ \text { 14. } & \text { Pagano, 115. } \\ \text { 15. } & \text { Pagano, 125. }\end{array}$


pasando, aunque su conocimiento me produ jera grandes dolores y me hiciera vivir en constante zozobra."16

The Reynafé brothers align themselves with General López because they do not trust Quiroga; they doubt the sincerity of his commitment to the Federalist cause and regard him as an opportunist who wants control of Córdoba in order to insure his power base. Pagano's Lorenza remains actively engaged, sending and receiving messages and protecting as much as possible the family's possessions, though many go to support the military cause.

As a major landowner, Lorenza's brother José Vicente assumes the position of Governor of Córdoba in August of 1831, while, according to the novel, from the start she put herself to work for him as an unpaid collaborator. When her brothers get together to discuss the seriousness of the state of affairs, Lorenza takes part in the decision making process, and receives the approbation of the brothers for her thoughtful commentary: Nevertheless, she is aware that she has become involved in what may, and in reality does, have dire repercussions for her family and the country:

Sabía que eso [mi opinión] daba por terminada cualquier disputa, pero no me alegré, porque estaba segura de que acababa de formalizarse un duelo secreto entre Quiroga y los Reynafé, cuyo desarrolloera imprevisible y su consecuenciafinal, ladesaparción (sic) de uno de los rivales de la escena del país. ${ }^{17}$

Later Lorenza will reflect on how important her political involvement was to her life:

al fin me encontré metida hasta las cejas en los vaivanes del gobiemo, obligada a poner toda mi atención en él y a vivir en

16. Pagano, 155 .

17. Pagano, 177. 
estado de alerta permanente, a tal punto que lo demás, el universo que estaba fuera del ámbito político, prácticamente había dejado de existir. ${ }^{18}$

Increasingly, though Lorenza keeps abreast of activities, advises her brothers, and suspects the disastrous consequences of the family's involvement in this historical period, she is unable to prevent the tragedy. At different times in the novel, Lorenza gives voice to one or another of the varying theories about the Reynafé's involvement. At one point she voices what has been one of the contentions of some historians: that the brothers were pawns in a war for power that had little to do with the basic conflict itself:

...presiento que las tan fundamentales cuestiones tienen que ver con el riojano y con el duelo que Francisco sostiene con él. Rosas y López recelan de Quiroga y éste a su vez desconfía de ellos. Espero que no sean los Reynafé el medio para ejecutar los planes que estos tres señores que se dicen tan compañeros, han armado secretamente. ${ }^{19}$

The narrator adds: "Sabe que la tragedia está ahí, acechando a su familia y que ya nada podrá detenerla". 20

Also, as the situation increases in intensity, the fictional Lorenza surmises that her brothers are making plans without consulting with her. Thus, she cannot know the "truth" of the situation. Several pieces of information that Lorenza relates seem to implicate the brothers in the assassination of General Quiroga. She recounts a time when her brother Pancho says to her that: "si tú matas por odio, cometes un pecado, un crimen, pero si lo haces en tu defensa, practicas una

\begin{tabular}{l}
\hline 18. $\quad$ Pagano, 292. \\
19. $\quad$ Pagano, 196. \\
20. $\quad$ Pagano, 214.
\end{tabular}


virtud". ${ }^{21}$ Later, finding it impossible to believe that her brother José Vicente could be actively involved, she questions if he had done all that was possible to prevent the participation of the others .

Facundo Quiroga is assassinated at Barranca Yaco in 1835; the gaucho Santos Pérez and his men are apprehended for the deed, and the arrest of the Reynafé brothers is ordered. Francisco escapes to Uruguay where he later dies in the battle of Cayasá; José Vicente, Guillermo and José Antonio are detained and sent to prison in Buenos Aires. José Antonio sickens and dies in jail. In 1837 José Vicente and Guillermo are executed publicly.

When they are accused, the fictional Lorenza tries to console the family and assure them of the innocence of the brothers, even while she notes that: "a mí las dudas me desvelaban y no podía comentarlas a nadie". ${ }^{22}$ She decides to help prepare their defense and "de jar para más adelante mis dudas y poner todo mi esfuerzo en tratar de salvar a mis hermanos". 23

As she collects evidence she comes to see other possibilities (other historical theories) which may even involve Rosas: "Quizás los Reynafé habían planeado en efecto el asesinato de Facundo, ¿pero si alguien se hubiera adelantado? Algunos de los papeles que estaban en mi poder abrían esa posibilidad y yo quería aferrarme a ella."24

In the end Lorenza attends the execution and later learns of the death of Francisco in the battle of Cayasá. She moves to Buenos Aires, partly because most of the family properties have been confiscated, but mostly because of the memories associated with Córdoba and its environs. There she remains the rest of her days, alone and wondering if all of her sacrifice and activity were worth it: "Y mi gran pregunta — ¿valió la pena? - seguía sin respuesta." ${ }^{25}$ Through the telling of her

\begin{tabular}{ll}
\hline 21. & Pagano, 219. \\
22. & Pagano, 245. \\
23. & Pagano, 248. \\
24. & Pagano, 266-67. \\
25. & Pagano, 292.
\end{tabular}


story and the defining of herself as subject of the narrative, the fictional Lorenza justifies her existence and that of the historical women involved in nation building.

Because of the various conflicting historical accounts of the Quiroga assassination, the reader is likely to expect at first that the novel Lorenza Reynafé, told by a sister and trusted advisor of the four Reynafé brothers charged in the event, will reveal a "true" version about it. However, her ultimate admitted distancing from the decision making of her brothers and her own expressions of doubt about whether or not they were actually guilty of the assassination at the same time that she is amassing evidence in their favor, deconstructs the event and inclines not toward a clarification, but rather supports obfuscation and the pluralization of possibilities as well as an ultimate ambiguity: that the brothers planned and executed the assassination for the good of the emerging country, that they ruthlessly executed a rival leader; that they favored the event but were not directly involved in planning it; that some of the brothers were actively involved and other(s) not; or alternately that they were scapegoats of either a jealous Estanislao López or a dictatorial Rosas who had the assassination carried out to get rid of a powerful rival. There are also a couple of additional intriguing possibilities that the reader may surmise: that the brothers trusted advisor Lorenza helped plan the deed but does not choose to reveal to the reader her active participation, or alternately that Lorenza, also in her capacity as trusted advisor, could have prevented the tragedy by openly speaking to her brothers against any violent action when she was suspicious that her brothers were plotting.

Pagano develops her fictional story from the memories of a now aged Lorenza, the narration of a semi-omniscient narrator, and the letters to and from various family members and friends. Two of these sources are suspect in regard to their reliability; that is, Lorenza is at the telling 82 years old, a sister and advisor of the accused who may know more than she chooses to reveal or suffer from some loss of memory at her advanced age. However, the fact that she expresses 
doubts about the innocence of her brothers lends support to her trustworthiness.

Letters always present not only a very subjective viewpoint, but also a censured one, for the writer is always aware of the reader to whom the comments are directed. In this novel, nearly one third of the text is composed of letters to and from Lorenza, her brothers, other family members, friends and acquaintances. The letters add support to the details of Lorenza's telling of her story at the same time that they multiply the viewpoints, and reinforce the posture that there is no one accessible truth for historical events, and that all official versions must be considered as suspect. Carmen Perilli, writing about Elena Poniatowska's epistolary novel Querido Diego te abraza Quiela declares that: "la verdad no es tan importante como la denuncia de la ficción oficial." 26

Finally, the intertextuality of Lorenza Reynafé o Quiroga, la barranca de la tragedia is probably what most alerts the reader to the suspect nature of official historical accounts. Fictional works such as Gutierrez' which glorify the Reynafé brothers as martyrs (Juan Manuel de Rosas), or accounts such as Kirkpatrick's which call the brothers "fourunscrupulous adventurers" 27 individually take a position, right or left, black or white, guilty or innocent. In their totality they offer a confusing vision, but separately they purport to tell "the" true story. Pagano's novel makes no effort to define the truth; indeed the truth may be too diffuse to circumscribe. She leaves us with a story in all of its ambiguity, a lesson that perhaps there is no one version of any historical event, and a heightened awareness of what it means, as Rosa Isabel Galdona Pérez has affirmed: "jugar a inventarnos a nosotros mismos y hacer de la realidad una ficción y de la ficción una verdadera realidad. ${ }^{28}$ In addition, as indicated by the title, which pairs the name

26. Carmen Pirelli, "La increible y triste historia de Angelina Beloff y de su amante desalmado," Revista chilena de literatura (vol. 50, 1997, 133-139) 134.

27. F. A. Kirkpatrick. A History of the Argentine Republic (New York: AMS, 1969) 144.

28. Rosa Isabel Galdona Pérez, "De la representación linguística del mundo: sobre una ficción femenina en la España de la posguerra," Anuario de estudios filológicos XX $(1997,119-128) 119$. 
Lorenza Reynafé with that of Facundo Quiroga, the author is reminding the reader that there were women integrally involved in the stories of nation building, women who should be included in fact and fiction. 